\title{
Constructing Humanistic Library and Harmonious Campus
}

\author{
Renxiu Luo \\ Library, Jiangxi University of Science and Technology, Ganzhou 341000, China \\ Tel: 86-139-7079-0647_E-mail: 1xs9103@163.com
}

\begin{abstract}
The foundation of humanistic library in university is one of the important links of constructing harmonious campus. The paper discusses the function and importance of humanistic library in harmonious campus construction with several proposals as well.
\end{abstract}

Keywords: humanistic library, harmonious campus, humanistic spirit

\section{Introduction}

The Communist Party of China's Fourth Plenary Session of The Sixteenth Central Committee first completed the concept of building a socialist harmonious society. Since then, Hu Jintao and other Chinese leaders have conducted repeated investigations and made an important elaboration on the issue of building a harmonious society. In 2006, The Communist Party of China's Sixth Plenary Session of The Sixteenth Central Committee which became the focus of attention deliberated medium totally central concerning the decision which sets up socialism diapason some social important problems and focused on the issue of building a harmonious society. Building a socialist harmonious society is a great strategic plan proposed by the Communist Party of China Central Committee and one of the important goals of China's "11th Five-Year Plan" period of economic and social development.

Colleges and universities through training and dissemination of knowledge play a unique role in building a socialist harmonious society. On the other hand, as a part of society, colleges and universities must also build a harmonious campus as the major task of school reform and development. University library is one of the important components of higher education, whose main duty is to focus on teaching and research; meanwhile it is also a special role and account for a unique position in the construction of campus culture. University library should be student-oriented, meet the needs of the students, realize the value of the students, pursue the development of the students, reflect the humanistic spirit, and play its own advantages to promote harmonious campus building.

\section{The connotation of the humanistic library}

The concept, "humanities", is out of Book of Changes of Zhou Yi. "Humanities" in Book of Changes is relative to "astronomy". It is said in Book of Changes that "The rigid-flexible shifts are staggered, which is called astronomy. People's behaviors meet civilized manners, which is called humanities". So "humanities" is relative to the terms of "astronomy". A relatively great impact on the concept and significance of humanities is Humanism. Humanism is the dominant ideology in Western Renaissance period. It is also a new bourgeois ideology in the European Renaissance period, that is, people-oriented. And sometimes it is translated as "humanism".

The Chinese name of "Humanistic Library Science" is first proposed by Jiang yongfu. He points out that here, "humanities" means humanism in the thinking attitude sense, corresponding to the word "science" in scientism. He believes that the "Humanistic Library Science" is the appellation which is relative to the "Scientific Library Science", only an ideological advocate or school, rather than a branch of library science. "Scientific Library Science" is the focus of the scientific spirit in the library science while "Humanistic Library Science" emphasizes the humanistic spirit in the library science. Xiao Ximing thinks the humanistic spirit could reflect the people-oriented thinking in the practice and theoretical study of the library work, meet the needs of people, realize the value of human beings, pursue human development, reflect humanistic concern and create beauty and harmony as library activities purpose. Here, I believe that the humanistic spirit in the colleges and universities library should be: library should be student-oriented, respect the value and dignity of students, meet the needs of the students, create a good humanistic atmosphere, attach importance to education, improve students' quality and spiritual realm and make students foster lofty personality ideals to be healthy, free, all-round development.

\section{The importance and urgency of building humanistic library in colleges of science and engineering}

Library has a long humanistic tradition. In 1986 M. F Stegge stressed: "humanistic values are the core of library career." In 1987 E. G. Hawley said: "Our career is basically a humanistic career. Our goal is essentially people." Library as a cultural and educational institution has a long history for millennium. Its emergence and development have its own 
profound basis and its inherent mechanism. This support force is the distinctive and unique library spirit, including the professionalism and the humanistic spirit reflected by the people who engage in library work in practice. Whether in traditional library or modern digital library, the humanistic construction and the humanistic spirit are indispensable. The library without scientific spirit is not vital and lags behind. The library with the lack of the humanistic spirit is less humane and cold.

However, with the rapid development of science and technology today, this humanistic spirit is increasingly ignored by people. On the one hand, networks wave are rushing toward us, the office automation in the library has been continually improved, and the advanced information storage technology has also allowed library resources to break space limitations, at the same time the humanistic awareness of library is neglected. For example, the functions of the computer books circulation system are advanced but the collections still not be opened for the reader to implement the open-shelf borrowing; the staff operate computer proficiently but they service readers without their enthusiastic attitude. On the other hand, with the development of technology, the education system blindly pursues the scientific spirit so as to nurture professionals. However, due to the single disciplines in colleges of science and engineering, the small scale, the irrational structure and a lack of library books on humanities, the students nurtured in such an environment maybe have certain knowledge or technology with the spirit of hard work, but their knowledge is often narrow and cultural foundation is not solid with a lack of profound cultivation, especially the comprehensive literacy and the humanistic quality as modern. This phenomenon has to do with the lack of humanistic library in colleges of science and engineering. Therefore, colleges of science and engineering should speed up the construction of the humanistic library, because it is beneficial not only to the growth of talent, but also to building a harmonious society in China.

\section{The construction of humanistic library}

\subsection{Create a good humanistic environment}

Tao Xingzhi, a famous educator, said: "A vibrant, stable and harmonious, healthy and progressive atmosphere itself has a wide range of educational functions." Therefore, the setting of the library should be designed to fully reflect the humanistic spirit and provide a good environment and atmosphere for the development of students.

First, we should emphasize the humanistic characteristics on the building of library, from the design to the internal structure, to be close to the needs for use, emotion and psychology of readers. External environment should be carefully designed and created, such as the color tone to unification, and the sufficient emphasis on the visual aesthetic. Its architectural style and building image should not only be coordinate the buildings environment in the region but also have their own unique personality through the display of its architectural style and personality image to create a harmonious atmosphere between buildings and people, humans and nature. In addition, green the surrounding premises of the library and engage in afforestation with sculptures, fountains, lawns and flowers to embellish the environment, to create a rich cultural atmosphere of the library. After a lengthy reading, the readers here can enjoy the natural scenery, relieve fatigue and improve learning efficiency.

Second, the indoor environment of the library should be designed to follow the reader-oriented principle based on the aesthetic sense, using the color match, the formal contrast, the level arrangements, the reciprocal style and the embedded decoration etc. to create a quiet, elegant and comfortable reading environment. For example, choose the evergreen plants, which have the function of air purification such as Evergreen and Chlorophytum. This will not only beautify the indoor environment, but also purify the air with bringing readers a good psychological and physical feeling. In addition, the furnishings should have profound cultural connotation. For instance, sculpture can be placed in the room. We could also post some murals, calligraphy and famous celebrities etc. on the wall. These layouts not only beautify the indoor environment but also purify the readers' soul.

\subsection{Establish a "people-oriented" service concept}

To meet the needs of the students, realize the value of the students and pursue the development of the students, the important thing is that librarians should establish a student-oriented service concept, because it is necessary to treat others with sincerity, carry conviction by emotion and reason and give each student the respect of personality fully, humanistic care and human warmth. Only in this way can we win the trust of readers, embody the concept of the humanistic spirit and make readers take full advantage of the various library information resources. In addition, the comprehensive quality of librarians should be enhanced. First the librarians must emphasize scientific literacy, constantly improve their attainments, and then master the modern, digital and Internet-based skills. Secondly librarians should improve their own moral cultivation, so that they can play a positive role as teachers in work style, service attitude, demeanour and other aspects for the purpose of management and education.

\subsection{Rich collections of information}

The construction of information resources is the most important task for the library and is the material basis of external services. When correctly handling the proportion of the various structures and providing literature information comprehensively and balancedly for each subject, specialty and course, it is necessary to adjust the structure, increase 
the collection of the books on the humanistic and social sciences and largely introduce the books which can improve the cultural quality and taste of students. Only in this way can we fully meet the reading needs of students so that students can widen their view, integrate their knowledge structure, increase their hobbies and fully be stimulated the creativity and imagination.

\subsection{Add multi-function service room}

In order to meet the diversified demands of readers, the architectural design of modern university library should develop in the direction of multi-function in addition to the original function, and provide readers with a broad and stretch of space. For example, establish audio-visual room, lecture hall, exhibition hall, academic research studio and speech hall etc.

\section{Conclusion}

Colleges and universities are the cradles of cultivating students and library as an educational and cultural centre of colleges and universities plays an important role in building a harmonious campus. Creating humanistic library is our goal to be pursued. And the building of a harmonious campus is our ultimate goal. We should take the humanistic spirit as guidance for the library's ideological work, establish a people-oriented concept to service students, and make full use of library's own advantages in order to promote the building of harmonious campus and harmonious society.

\section{References}

Huang, Juping. (2000). On establish humanistic library in colleges of science and engineering [J]. Shandong Library Quarterly, (3), 32-34.

Jiang, Yongfu. (2002). Outline of the humanistic library science [J]. Chinese Library Science Journal, 28 (4), 9-13, 58.

Xiao, Ximing. (2001). Library calls for the integration of the scientific spirit and humanistic spirit [J]. Library, (1), $11-11,10$.

Xu, Ying. (2002). Urban Sociology [M]. Jinan: Qilu Press.

Zeng, Xiaoshan \& Zhang, Ying. (2004). On the connotation, the core ideas and principles of humanistic spirit [J]. University Library work, 24 (1), 57-58. 